\title{
PLAY HERMENEUTICS AGAIN, SAM
}

Bruce Krajewski

"There are no things to be, / Only a detective."

\section{-John Ashbery, "Nothing to Steal"}

IN The Maltese Falcon, Sam Spade, Joel Cairo, and Brigid O'Shaughnessy quarrel in Spade's room, and the police arrive and want to take all three to the police station. Spade, however, invents a story to explain the quarrel, confuses the police, and causes the authorities to think that the skirmish was concocted, a ruse for the trio's entertainment. The next morning, Spade meets Cairo in a hotel lobby, and Cairo says he has been up all night. He claims the police took him in for questioning.

"What they shake out of yuh?" Spade asks.

"Shake out? Not one thing. I adhered to the course you indicated earlier in your rooms, but I certainly wish you would have invented a more reasonable story. I felt distinctly like an idiot repeating it."

Spade replies, "Don't worry about the story's goofiness. A sensible one would have had us all in the cooler."1

At present, you are in the same situation as the police when they hear Spade's odd, contrived explanation about the quarrel. What is he talking about? Why is he telling us this? Quite an alien way to begin a paper. He must be goofy.

What do you do when you encounter something alien or goofy? Many times, you dismiss it, claim that it is esoteric, impenetrable, senseless, foolish, or even more extreme, insane. For instance, suppose you have never seen King Lear, and you arrive at the theatre during Act III, Scene IV when Gloucester asks Edgar who he is, and Edgar responds:

Poor Tom, that eats the swimming frog, the toad, the todpole, the wall-newt, and the water, that in the fury of his heart, when the foul fiend rages, eats cow.dung for sallets; swallows the old rat and the ditch-dog; drinks the green mantle of the standing pool; who is whipt from tithing to tithing, and stock-punish'd and imprison'd; who hath had three suits to his back, six shirts to his body-Horse to ride, and weapon to wear; But mice and rats and such small deer, Have been Tom's food for seven long year. Beware my follower. 
Edgar says he is Tom? And what is all this gibberish that Edgar, or Tom, is uttering? Surely Edgar has lost his mind. ${ }^{2}$

Sam Spade's goofy story and Edgar's speech are certainly not things we would write, because, as Richard Lanham says, most of us are taught the C-B-S theory of writing: clarity, brevity, and sincerity. ${ }^{3}$ Lanham sees two types of prose: transparent and opaque. ${ }^{4}$ We want, and expect, people to write prose that is as clear and transparent as cellophane wrapping, and just as disposable. Opaque prose stops you at the surface, as Edgar's speech does. You cannot see through it, for it is dark, bewildering, unsettling. It is something that claims our attention. For some reason, our writing textbooks tell us to be always clear, that the best style is the never-noticed. We think people should be as literal as possible. Today, anyone who wrote like Shakespeare would be considered "odd."

Ancient interpreters and rhetoricians thought differently. Rhetoricians have understood for centuries that sometimes to make things plain, you need to darken them, or make them obscure. How do things become clearer by darkening? For instance, a black and white photograph contains sharp dark areas, deep blacks that make the light areas more distinct. You might have surmised by now that the ancients divided texts into the plain and the obscure, and naturally they preferred the obscure ones. Without being simplistic, you could say that the ancients believed something like this: "that that which is easy to understand is not worth understanding except for those who can understand nothing else." 5 They saw also that what is obscure is often valuable.

When you know that something is "wrong" with what you are readingthat is, when you discover that what is written, or spoken, is garbled, contradictory, unbelievable, like Edgar's speech-then you know it is trying to speak to you, to draw you into its secrets, its darkness. "After all, if everything were plain, nothing would be required to be studied; everything would be commonplace-much would be known but little would be understood."6 That which does not require interpretation requires little, if any, thought. Being in an enigmatic text, or being in the dark often leads to insight, and to understanding. You will recall that Gloucester begins to make accurate glosses on life only after he is blind.

Similarly, Sam Spade deals only with difficult, mysterious cases. If the case is plain, clear to ordinary understanding, then there is no need for a detective, an interpreter. The case of the Maltese falcon appeals to Spade because of its complexity and darkness. The falcon itself is said to be dark. Its value is not obvious, for though it is encrusted with jewels, it has been covered with a coating of black enamel. To some people who have had possession of the falcon it has meant nothing. They were not stopped, drawn in, by the surface. They dismissed its dark covering. To them, it was merely a black enameled figure. 
We can say that the falcon is an example of figuration. Think of figuration as darkening, say coating something with enamel, or writing something, putting black on white, darkness on paper, and we can comprehend darkness by learning about figuration, by perhaps even composing our own metaphors, allegories, fables, and what Joel Cairo would call "goofy stories." Allegories and the like are discourses that can be taken in more than one way, like a goofy story-discourses whose surplus of meaning produces not negation, but new sources of understanding. That which requires interpretation requires thought. Is it reasonable to think that were we to construct an enigmatic text, we would then be better able to understand other dark works?

Also, we should attend to characters like Sam Spade, because he is not plain, obvious, predictable - as is the insipid prose we write when we want to be perfectly clear. As his name suggests, Spade is a dark character. In fact, Brigid O'Shaughnessy calls Spade the wildest, most unpredictable person she has ever known. And Kaspar Gutman, the man who has spent years searching for the falcon, says to Spade: “There's never any telling what you'll say or do next, except that it's bound to be something astonishing." In other words, Spade is not always the same; he knows what a situation calls for and acts accordingly.

Spade's astonishing actions and his goofy stories, applied judiciously, prevent him from coming under the control of the police, or of Gutman. As you remember, Spade says a sensible, plain story would have resulted in his arrest along with the others. In such a situation, to be plain would be foolish. Encouraging people to write everything plainly is foolish as well. Not only does such a method deny changing means for changing situations, but it also denies that some people might not have "plain" personalities that would manifest themselves in other than a plain style. Making people think that clarity suffices in every situation subjects them to possible manipulation by others, gives others power over them. As Lanham says, "Articulate speech can get you into trouble."?

Although I sidestepped an important question earlier, now is the appropriate time to re-introduce it: What do you do when you encounter something alien or goofy, like Edgar's speech or the story Spade tells the police? If you are open to such situations, and wish to understand instead of to dismiss, if you wish to make the alien familiar and sensible, hermeneutics can help. Hermeneutics is not a method or a set of rules for interpretation, but a blossoming and difficult family of questions about understanding that comes down to us from antiquity, and in modern times by way of Martin Heidegger and Hans-Georg Gadamer, particularly Gadamer's book Truth and Method.

The expression "hermeneutics" derives from the Greek verb hermeneuein. As Heidegger tells us, that verb is related to the noun hermeneus, which is referable to the god Hermes. Hermes is the divine messenger. Since he has 
communication with the gods, he brings the message of destiny; hermeneuein is that exposition which brings tidings because it can listen to a message. Hermeneuein means to bring what is hidden out into the open; it means to interpret.

Given that Hermes carries words from the gods, his messages were often oracular, ambiguous, strange, and his appearance was not always welcomehe was said to lead the souls into the underworld at death. Hermes invented language and speech. In the Cratylus, Socrates points out that Hermes could be called interpreter or messenger, but also thief, liar, or contriver. You might call him an earlier version of Sam Spade. Socrates says that words, Hermes' invention, have the power to reveal, but also to conceal, and to withhold. Speech can signify almost anything, and turn things this way and that; indeed we can never get a grasp on words, hold them still, fix them (as if there were something wrong with them). Words' meanings always change, because contexts are always changing. It is in the Cratylus that Hermes begins to receive a tainted reputation. You might find Hermes even more puzzling and interesting when you remember that his son is some sort of mutant, smooth and divine above and goatlike below. Viewed as a freakish creature, Pan looks much less attractive than when we recall Cummings, who called Hermes' son "the little lame balloon man who whistles far and wee."

It is appropriate that Hermes is associated with hermeneutics, because Hermes is a messenger, someone whose existence and purpose depend on dialogue. He takes messages from god to god, or from the gods to mortals; he is the embodiment and the movement of discourse. "From the side of hermeneutics, we can say that to understand anything means to enter into a dialogue with it."8 Dialogue is the give-and-take between two, the question and response, the circular movement. That dialogue is primary to understanding shows that understanding is a social, not a private act, nor a mental operation. Thus Wittgenstein's statement that there is no such thing as a private language. (Also, Wittgenstein notes the importance-for understanding - of what is not plain, not quotidian: "How does one know straight off that it makes sense to say 'Perhaps everything strikes this person as unreal [unwirklich], although he never speaks of it'? Of course I have here purposely chosen a very rare experience. For because it is not one of the everyday experiences, one looks more sharply at the use of the words." $)^{9}$

Dialogue as a way of understanding between people can be reasonably accepted, but we want to ask the question: How do you enter into a dialogue with a text? Let me offer you some words from an essay titled "Verbal Interaction," which has been attributed to the Russian critic Mikhail Bakhtin. He says that dialogue is not restricted to "direct face-to-face vocalized verbal communication between persons, but also verbal communication of any type whatever. A book, that is, a verbal performance in print, is also an element of verbal communication."10 
This part about books as part of a dialogue is strange (a clue to its importance). What do you say to a book? Well, you always have questions about a text: What does it mean? Who is its author? Why was it written? What was the social situation at the time it was written? Who put it in the marketplace? What question is this text an answer to? Why is the text constructed in this manner? As in the Platonic (play-tonic) dialogues, the dialogue with a text begins with questioning. You will know you want to understand when you start questioning. And the text can answer those questions; it can speak to you, and thus be a partner in the dialogue.

Perhaps this can be better understood through Paul Ricoeur, another important figure in modern hermeneutics. He says, "What must be interpreted in a text is a proposed world which I could inhabit and wherein I could project one of my own most possibilities. This is what I call the world of the text, the world proper to this unique text." 11 The text proposes a way of being in the world (might a variation of Wittgenstein be appropriate here: A text's meaning depends on its usage?). Ricoeur emphasizes that appropriation, which I will address in a moment, is a key part of hermeneutics, and that ultimately, what you appropriate is that proposed world of the text. "That world is not behind the text, as a hidden intention would be, but in front of it, as that which the work unfolds, discovers, reveals."12

Here, The Maltese Falcon as film can be introduced as a supporting analogy, for when talking about a projected world, what is more appropriate than film? To carry through with Ricoeur's image, we could imagine ourselves standing in the light from the projector (one must activate the projector oneself) that is showing The Maltese Falcon, and we would then not be a shadow in that world, but a participant, perhaps Sam Spade's friend. This conflicts with the idea of a "close reading," because to be close to the beam is still to be outside of the projected world. You must enter the world. To understand is to be let in on something, so you let yourself go in to the world projected by the text, somewhat like Alice stepping through the Looking Glass. Even if you are close, you are still an outsider, on your side of the looking glass, and the text remains an object, for there remains a distance between you and the text. This idea of the dialogue also suggests something other than a critical reading, for a critical reading removes the possibility of a dialogue. Can you enter into a dialogue with someone or something that has got you under analysis? ${ }^{13}$

What you do when you allow the text to speak to you is to make its meaning real for you, to appropriate the text, that is, to make it your own. When you make a text your own, you are able to tell someone else what the text has to say. You make your own what was initially alien. The aim of all hermeneutics is to struggle against cultural distance and historical alienation. Interpretation renders contemporary and similar, or in Wittgenstein's words, it helps things "hang together." In effect, the past appears through a text (though the past appears in other ways) and has something to say to you as reader, and you listen, take in what it says, and respond. ${ }^{14}$ 
Here again we see the give-and-take, the speaking and the listening, the to-and-fro movement of appropriation. As Gadamer says, this to-and-fro movement is like play. ${ }^{15}$ Think of play as a way to appropriation, for play is the performance of movement. When you read a text, you are receiving an invitation to undergo an imaginative variation of your ego. The Looking Glass beckons Alice to move, to enter. She is not to remain outside, staring at herself in the looking glass, but her task is to stop seeing only herself, to lose herself by stepping through the mirror. Ricoeur says, "As reader, I find myself only by losing myself." Like Alice, after you are in the world of the text, you are no longer the same. Likewise, play is an experience which transforms those who participate in it. For instance, there is a curious lack of decisiveness in the playing consciousness, which makes it impossible to decide between belief and non-belief. Gadamer says that "play fulfills its purpose only if the player loses himself in his play." 16 Here, play is serious, and Claude Richard says, "The basis of modernity is the seriousness of playfulness."17 Think of Wittgenstein's "language-games."

What does this have to do with a work of art, a text? Gadamer's response is:

The work of art has its true being in the fact that it becomes an experience changing the person experiencing it. The 'subject' of the experience of art, that which remains and endures, is not the subjectivity of the person who experiences it, but the work itself. This is the point at which the mode of being of play becomes significant. For play has its own essence, independent of the consciousness of the those who play.

The players are not the subjects of play; instead play merely reaches presentation through the players. ${ }^{18}$

Similarly, a text can reach presentation only through a player, a participant, a reader, one who is willing to be hermeludical.

Another part of appropriation involves what is called the hermeneutical circle, something hermeneutics appropriated from ancient rhetoric, which describes how the ways of understanding and interpretation, part and whole are related in a circular way: in order to understand the whole, it is necessary to understand the parts, while to understand the parts it is necessary to have some comprehension of the whole. For instance, you will recall the situation I mentioned concerning entering a theatre in the middle of a performance of King Lear. Edgar's speech makes little sense severed from the whole. Why Edgar pretends to be Tom becomes clear only when you have the rest of the pieces, and then you can construct a plausible context in which to place Edgar's words.

Gadamer has described the hermeneutical circle as the interplay of the movement of tradition and the movement of the interpreter. Interpretation stands in and is conditioned by tradition, and is necessarily rooted in a historical situation. How might we be conditioned by tradition? For instance, our understanding is conditioned by the historical accumulation of previous interpretations, by the history of things themselves, and, as Jürgen Haber- 
mas points out, by those who control the production and distribution of texts. Unless you know the history of the Maltese falcon, it will be merely a cheap ornament to you. Once you know that it is studded with jewels, then its value is revealed (or is it important that the characters believe it has value, and that they act on that belief?). As for the historical accumulation of interpretations, we pay attention to King Lear, because our ancestors have told us it is a great drama. In addition, we do not take Lear to be a play representing a unique form, for we know that many tragedies came before Lear. To recognize tradition is to see that we are in history, and that history, which is mediated by texts, has a claim on us. Since history is always changing, and since interpreters change over time through increased experience, we can say that we are always understanding differently, which explains why our understanding of Lear differs from that of a 17 th-century interpreter. History gives us precedents for new interpretations, just as laws are altered according to new circumstances. If you think of the law as a text, you see that the law is not static, but fluid, changeable, and laws are applied differently in time. The issue of precedents brings up Gadamer's point that in order to understand the past, it is necessary to try to comprehend one's own presuppositions and prejudgments in order to realize how these mediate one's perception of the past.

You might ask, why bother with texts from the past? From a hermeneutical viewpoint, a work of art is precisely that about which we cannot be indifferent. The artwork is historical not in being a moment in history, but rather being a condition for, or even a generating force of, subsequent cultural achievements. Hermeneutics does not allow for disinterestedness. We must become aware of our historicity, because we are in history, and because a better understanding of history can lead to fuller self-understanding. Ricoeur tells us "it must be said that we understand ourselves only by the long detour of the signs of humanity deposited in cultural works. What would we know of love and hate, of moral feelings, of all that we call the self, if these had not been brought to language and articulated by literature?"19 Understanding the past might also yield truth. Is it true that the truth of things lies in their history?

Let us go back in the history of this paper to the example of the detective. For the moment, think of Spade not as an individual, but as a type of individual, namely the detective. As a detective, Spade unearths things, uncovers them, brings them out into the open. You recall that we characterized interpretation this way, as a bringing of what is hidden into the open. The Greek verb hermeneuein means this same thing, to interpret. Thus we can say fairly that detectives are hermeneutical characters. They enjoy enigmas, and are always involved in mysteries. They gather clues, that is, parts of the whole, and try to see how the parts, the clues, make the whole comprehensible. Surely, we think of detectives as people who are involved, and who are often in danger, which means the case makes a claim on them. 
For example, the case could claim the detective's life. It seems there is much to be learned from detectives, even poor ones.

What can we learn from a poor detective? Consider the detective named Mr. G-, Prefect of the Parisian Police, in Poe's "The Purloined Letter," a work which "has become the arena where one of the fundamental debates of contemporary criticism is being held."20 Poe says the Prefect "had a fashion of calling everything 'odd' that was beyond his comprehension, and thus lived amid an absolute legion of "oddities."'21 Mr. G- wants to locate a letter in the possession of Minister $\mathrm{D}-$, a letter which gives the minister a good deal of political power. The Prefect has applied his methods diligently, using microscopes, sticking needles into the bindings of Minister D-'s books, checking for cavities in the furniture where the missing missive might be hidden, but the Prefect comes up empty, so he turns to Dupin, who, through dialogue, spots the difficulty immediately. Dupin explains that the Prefect's measures "were good in their kind, and well executed; their defect lay in their being inapplicable to the case, and to the man...."22 "[The Police] consider only their own ideas of ingenuity; and, in searching for anything hidden, advert only to the modes in which they would have hidden it." 23 All that the Prefect has done, Dupin says, is but "an exaggeration of the application of the one principle or set of principles of search."24

Dupin and Sam Spade are hermeneutical characters, because they understand the principles of ancient rhetoric. Knowing how to adapt to particular situations and particular characters or audiences is what Aristotle's Rhetoric is all about. What the Prefect is lacking in his efforts to find the letter is what Aristotle calls phronesis, practical wisdom. ${ }^{25}$ As Dupin tells us, the Prefect applies the same methods regardless of the case. Thus his method is ahistorical. Reliance on a single method-even a method of criticism-ignores the historicity of things, and denies that particular situations call for varying approaches, just as different audiences call for different speeches. Sam Spade pays attention to Aristotle, for he realizes that an audience composed of police in his rooms calls for a goofy story. Continually, Spade illustrates his resourcefulness. He gets Brigid O'Shaughnessy to admit that she committed murder. After she confesses, she says to Spade: "You've been playing with me; just pretending you cared, to trap me like this." Here we see Spade violated the ' $\mathrm{S}$ ' in the C-B-S theory of living: He was not sincere. Had he been sincere, he would not have solved the case. The situation with Brigid did not allow for sincerity.

The situation Dupin finds himself in when he goes to the Minister's hotel does not call for sincerity either, for Dupin must discover a way to look for the letter without drawing the Minister's suspicion. So Dupin dons dark glasses (Why green? A color that indicates Dupin's fertile vision?), and pretends to have weak sight. Barbara Johnson says, "Dupin's feigned blindness is a vigilant act of lucidity." 26 As Gloucester is able to discern better in darkness, so Dupin sees remarkably well in his dark and "duplicitous" 
world. ${ }^{27}$ In fact, Dupin says at the beginning of the story: "If it is any point requiring reflection, we shall examine it to better purpose in the dark."28 By seeing that his meeting with the minister calls for dark glasses, and by seeing that certain kinds of thinking are suited for darkness, Dupin, like Spade, illustrates that good detectives know their ancient rhetoric.

Since antiquity hermeneutics has had an allegiance with rhetoric:

Where, indeed, but to rhetoric should the theoretical examination of interpretation turn? Rhetoric has been the only advocate of a claim to truth that defends the probable, the eikos, and that which is convincing to the ordinary reason, against the claim of science to accept as true only what can be demonstrated and tested! Convincing and persuading without being able to prove-these are obviously as much the aim and measure of understanding and interpretation as they are the aim and measure of the art of oration and persuasion. ${ }^{29}$

To return to "The Purloined Letter" by way of rhetoric, I am not directly entering into the debate between Lacan and Derrida, which has been explored by others, because that is not my purpose here. ${ }^{30}$ However, Barbara Johnson's comments in her review of Derrida's and Lacan's approaches to Poe are appropriate in relation to Gadamer's remarks about rhetoric and the probable. Johnson writes: "If the letter is precisely that which dictates the rhetorical indetermination of any theoretical discourse about it, then the oscillation between unequivocal statements of undecidability and ambiguous assertions of decidability is precisely one of the letter's inevitable effects." 31 To put it less precisely, the letter, like an allegory, can be taken in more than one way, and thus its multiplicity of meaning gives us new opportunities for interpretation.

\footnotetext{
“There's no mystery here!"- but then how can we have so much as believed that there was one?-Well, I have retraced the path over and over again and over and over again been surprised; and I never had the idea that here one can understand something-So "There's no mystery here!" means "Just look about you!"s2
}

NOTES

1 All quotations from The Maltese Falcon are taken from the script printed in The Maltese Falcon, ed. Richard J. Anobile (New York: Universe Books, 1974).

2 "The voice that assumes madness and its language in a text is playing at madness, for true madness would leave in its wake only silence. But one can play with the voices of dementia, invent games for fallen language, and seek play strategies that convert this language of otherness into literary language." From Allen Thiher's chapter "Play" in Words in Reflection (Chicago: University of Chicago Press, 1984), p. 156.

3 Richard Lanham, Literacy and the Survival of Humanism (New Haven: Yale University Press, 1983), p. 10.

4 Lanham, pp. 58-86.

5 Gerald L. Bruns, "Figuration in Antiquity," in Hermeneutics: Questions and Prospects, ed. Gary Shapiro (Amherst: University of Massachusetts Press, 1984), p. 148.

6 Bruns, p. 153.

7 Lanham, Style: An Anti-textbook (New Haven: Yale University Press, 1974), p. 11.

8 Bruns, "Structuralism, Deconstruction, and Hermeneutics," Diacritics (Spring, 1984), p. 13. 
9 Ludwig Wittgenstein, Remarks on the Philosophy of Psychology, trans. G.E.M. Anscombe (Chicago: University of Chicago Press, 1980), p. 156.

10 V.N. Volosinov, Marxism and the Philosophy of Language (New York: Seminar Press, 1973), p. 95.

11 Paul Ricoeur, Hermeneutics and the Human Sciences, trans. John B. Thompson (Cambridge: Cambridge University Press, 1981), p. 142.

12 Ricoeur, p. 143.

13 Bruns, "Structuralism, Deconstruction, and Hermeneutics," p. 14.

14 This is not to say that history is texts. In "The Politics of Reading Formations: The Case of Nietzsche in Imperial Germany (1870-1919)" in New German Critique (Spring/Summer '83), Geoff Waite stresses how problematic such a statement can be:

Although I view as empiriocritical, culturally elitist, and class interested the notion that "the bases for historical knowledge are not empirical facts but written texts, even if these texts masquerade in the guise of wars or revolutions," [He is quoting from de Man's Blindness and Insight] I take it as a significant truism the notion that what we know of history is mediated . . . by extant written documents. But this knowledge is thus mediated further by the ideological position of the class that possesses, controls, and disseminates the power to write and to read. (pp. 185-86)

15 See Gadamer's chapter "Play as the Clue to Ontological Explanation," in Truth and Method (New York: Seabury Press, 1975), pp. 91-119.

16 Gadamer, p. 92.

17 Claude Richard, “Destin, Design, Dasein: Lacan, Derrida, and 'The Purloined Letter," Iowa Review, 12 (Fall, 1981), p. 1.

18 Gadamer, p. 92.

19 Ricoeur, p. 143.

20 Richard, p. 1.

21 Edgar Allan Poe, Selected Works (Middlesex: Penguin Books, 1967), pp. 330-31.

22 Poe, p. 339.

23 Poe, p. 340.

24 Poe, p. 341.

25 Also see Gadamer's appropriation of phronesis, p. $20 \mathrm{ff}$ and p. $278 \mathrm{ff}$.

26 Barbara Johnson, “The Frame of Reference: Poe, Lacan, Derrida," Yale French Studies, 55/56 (1977), p. 468.

27 Ross Chambers says that Dupin's practice as a detective is the practice of duplicity. See Chambers' chapter "Narratorial Authority and 'The Purloined Letter" in Story and Situation: Narrative Seduction and the Power of Fiction (Minneapolis: University of Minnesota Press, 1984). According to Chambers, "We may say that the art of duplicity involves the production, and indeed the ostentatious display, of a deceptive externality intended to conceal an inner truth, the discovery of which would render the perpetrator vulnerable to loss of honor, dignity, or authority" (p. 62).

28 Poe, p. 330.

29 Gadamer, Philosophical Hermeneutics (Berkeley: University of California Press, 1976), p. 24. 30 Johnson's article is a thorough account. Also see Donald Pease, "Marginal Politics and 'The Purloined Letter': A Review Essay," Poe Studies, 16 (1983), pp. 18-23. The texts to which Johnson and Pease refer are: Jacques Lacan, "Seminar on 'The Purloined Letter,"' trans. Jeffrey Mehlman, Yale French Studies, 48 (1973), pp. 38-72; and Jacques Derrida, "The Purveyor of Truth," trans. Willis Domingo, James Hulbert, Moshe Ron and M.-L.R., Yale French Studies, 52 (1975), pp. 31- 113.

31 Johnson, p. 504.

32 Ludwig Wittgenstein, Remarks on the Foundations of Mathematics (I, Appendix II, p. 4). 